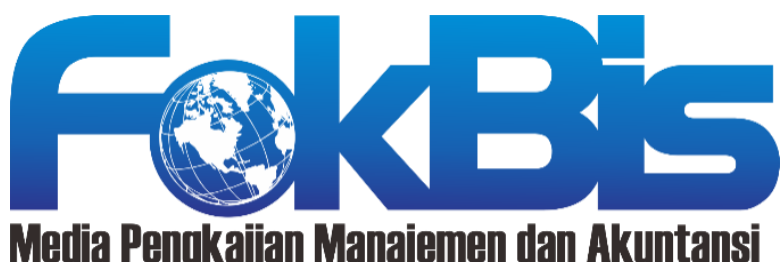

http://journal.stieputrabangsa.ac.id/index.php/fokbis/index

ISSN: 2623-2480/ P-ISSN: 1693-5209

\section{Faktor-Faktor yang Mempengaruhi Pengungkapan Lingkungan dengan Komite Audit sebagai Variabel Moderasi}

\author{
Alifia Riyadlotus Sholihah ${ }^{1}$, Diah Hari Suryaningrum ${ }^{2}$ \\ ${ }^{1,2)}$ UPN "Veteran" Jawa Timur \\ email: 17013010044@student.upnjatim.ac.id ${ }^{1}$
}

\section{Article Information}

\section{History of Article:}

Received May 9th 2021

Accepted May 24th 2021

Published July 31 2021

\section{DOI:}

10.32639/fokusbisnis.v19i2.805

\begin{abstract}
ABSTRAK
Pengungkapan lingkungan di Indonesia masih rendah karena belum ada pedoman yang pasti untuk pelaporan kinerja lingkungan perusahaan. Tujuan penelitian adalah untuk menguji dan membuktikan serta mengetahui komite audit memperkuat pengaruh faktor pengungkapan lingkungan. Menggunakan data sekunder dan jenis penelitian kuantitatif. Populasi penelitian 104 perusahaan yang terdiri dari perusahaan sektor pertanian dan sektor industri dasar \& kimia terdaftar di BEI. Menentukan sampel menggunakan metode purposive sampling diperoleh 12 perusahaan dengan periode 2015-2019 sehingga diperoleh 60 data. Teknik analisis data menggunakan regresi linier berganda. Hasil penelitian menunjukkan bahwa ukuran dewan komisaris berpengaruh positif terhadap pengungkapan lingkungan. Ukuran perusahaan dan REM tidak berpengaruh terhadap pengungkapan lingkungan. Komite audit tidak dapat memoderasi faktor-faktor pengungkapan lingkungan.
\end{abstract}

Kata Kunci: Ukuran Dewan Komisaris, Ukuran Perusahaan, REM, Pengungkapan Lingkungan, Komite Audit

\begin{abstract}
Environmental disclosure in Indonesia is classified as low because there is no definite guidance for reporting the company's environmental performance. The purpose of the research is to test and prove that the audit committee strengthens the factors on environmental disclosure. This study uses secondary data and quantitative research types. The study population was 104 companies consisting in the agricultural sector and basic industry \& chemical sectors listed on the IDX. Determining the sample using the purposive sampling method obtained 12 companies from the 2015-2019 period to get 60 data. The data analysis technique in this study used multiple linear regression. The test results show that the size of the board of Commissioners positive effect on environmental disclosure. Company size and REM do not affect environmental disclosure. The audit committee cannot moderate environmental disclosure factors.
\end{abstract}

Keywords: The Size of the Board of Commissioners, Company Size, REM, Environmental Disclosure, Audit Committee 


\section{PENDAHULUAN}

Perusahaan dalam mewujudkan tujuan utamanya yaitu mendapatkan laba perusahaan juga harus bertanggung jawab memperhatikan kesejahteraan sekitar dan turut berkontribusi dalam menjaga kelestarian lingkungan. Mengabaikan tanggung jawab kesejahteraan lingkungan dapat menimbulkan permasalahan lingkungan yang menyebabkan terjadinya berbagai macam bencana (Kurniawan, 2019).

Kasus tingkat pengungkapan lingkungan masih rendah yaitu pada tahun 2019 Joko Widodo memaparkan bahwa ada 11 perusahaan menyebabkan kerugian bagi negara dengan total kerugian sebesar Rp 18,3 triliun. Kesebelas perusahaan tersebut melakukan pembakaran hutan dan kerusakan hutan. Selain itu, pemerintah juga masih belum dapat mengatasi kerusakan lingkungan yang masih saja terjadi dari kasus kebakaran hutan (Dewi et al., 2019).

Permasalahan lingkungan menimbulkan perhatian dari berbagai pihak, seperti masyarakat, kreditur, pemerhati lingkungan, pemegang saham dan pemerintah. Pemerintah sangat berperan penting dalam mengatur tata kelola industri agar tidak terjadi pencemaran lingkungan dan menyebabkan kerusakan lingkungan (Sari et al., 2018). Perusahaan industri menyebabkan keresahan masyarakat yang menuntut agar perusahaan transparan dalam pengungkapan kegiatan yang berpengaruh terhadap lingkungan sebagai bentuk tanggung jawab perusahaan. Tanggung jawab perusahaan dapat dilihat dari mekanisme tata kelola perusahaannya. Jika mekanisme tata kelola perusahaan tertata dengan baik memberikan informasi mengenai kegiatan perusahaan yang berdampak terhadap kelestarian lingkungan dan masyarakat maka tanggung jawab perusahaan sudah dilaksanakan dengan baik (Maulia \& Yanto, 2020).

Pengungkapan lingkungan merupakan pelaporan yang menjelaskan dampak kegiatan perusahaan terhadap lingkungan. Kegiatan perusahaan terhadap lingkungan meliputi daur ulang, pengelolaan limbah, pengelolaan karbon, emisi dan polusi. Meningkatnya kebutuhan terhadap informasi pengungkapan keberlanjutan menjadi pilar utama perusahaan seiring dengan meningkatnya kesadaran pemangku kepentingan dalam pengungkapan lingkungan (Wahyuningrum et al., 2020). Pengungkapan lingkungan sangat berperan dalam program-program pemerintah pengelolaan lingkungan, meliputi PROPER (Program Penilaian Peringkat Kinerja Perusahaan), AMDAL (Analisis Mengenai Dampak Lingkungan), dan sistem manajemen lingkungan (Kurniawan, 2019).

Salah satu faktor pengungkapan lingkungan adalah dewan komisaris, dewan komisaris memiliki kewajiban memberi nasehat kepada dewan direksi serta menjalankan keputusan dan bertanggung jawab sebagai pengawas. Dewan komisaris memiliki pengawasan yang baik terhadap manajemen dengan meminimalisir kecurangan dalam laporan keuangan yang dilakukan oleh manajer (Mutmainah \& Indrasari, 2017). Penelitian yang dilakukan Maulia \& Yanto (2020), Pratiwi \& Kurniawan (2020), dan Mutmainah \& Indrasari (2017) menunjukkan bahwa ukuran dewan komisaris berpengaruh terhadap pengungkapan lingkungan, sedangkan penelitihan yang dilakukan Suprapti, et al. (2019) dan Supatminingsih \& Wicaksono (2016) menunjukkan bahwa ukuran dewan komisaris tidak berpengaruh terhadap pengungkapan lingkungan.

Faktor lainnya yaitu ukuran perusahaan memiliki hubungan terhadap pengungkapan lingkungan, jika perusahaan besar lebih memiliki tanggung jawab sosial yang tinggi dan lebih menunjukkan kepedulian lingkungannya agar mendapat image baik terhadap stakeholder. Penelitian yang dilakukan Maulia \& Yanto (2020), Wahyuningrum, et al. (2020), dan Dewi \& Yasa (2017) menunjukkan bahwa ukuran perusahaan berpengaruh terhadap pengungkapan lingkungan. Sedangkan penelitian yang dilakukan Fashikhah, et al. (2018) dan Oktariyani \& Meutia (2016) menunjukkan bahwa ukuran perusahaan tidak berpengaruh terhadap pengungkapan lingkungan.

Kepentingan antara manajemen dan pemilik dalam mengoptimalkan semua kegiatan perusahaan untuk mendapat keuntungan yang lebih besar, hal tersebut memaksa manajer melakukan tindakan kepentingan pribadi atau diri sendiri dengan menggunakan tipu daya atas kebijakan pelaporan penghasilan agar laporan pendapatan perusahaan terlihat lebih baik dari sebenarnya seperti real 
earnings management. Manajemen yang melakukan real earnings management menggunakan pengungkapan lingkungan perusahaan sebagai upaya untuk mendapatkan dukungan dari para stakeholder dan memberikan image perusahaan yang baik kepada masyarakat (Pratiwi \& Kurniawan, 2020). Penelitian yang dilakukan Pratiwi \& Kurniawan (2020) menunjukkan bahwa real earnings management tidak berpengaruh terhadap pengungkapan lingkungan.

Komite audit dapat memberikan pendapat profesional dan independen atas laporan perusahaan, seperti laporan tanggung jawab sosial dan lingkungan. Penelitian yang dilakukan Supatminingsih \& Wicaksono (2016) menunjukkan bahwa rapat komite audit berpengaruh terhadap pengungkapan lingkungan. Penelitian yang dilakukan Yusuf, et al. (2020) menunjukkan bahwa rapat komite audit memoderasi profitabilitas terhadap corporate environmental disclosure, namun rapat komite audit tidak dapat memoderasi leverage dan ukuran perusahaan terhadap corporate environmental disclosure. Penelitian yang dilakukan Machmuddah, et al. (2017) menunjukkan bahwa rapat komite audit tidak dapat memoderasi manajemen laba terhadap pengungkapan lingkungan perusahaan.

Motivasi dilakukannya penelitian ini dikarenakan pengungkapan lingkungan di Indonesia masih rendah. Hasil penelitian yang menunjukkan bahwa pengungkapan lingkungan masih rendah yaitu penelitian yang dilakukan (Maulia \& Yanto, 2020). Hasil menunjukkan rata-rata tingkat pengungkapan lingkungan sebesar $41 \%$ hal ini dikarenakan di Indonesia belum ada pedoman yang pasti untuk pelaporan kinerja lingkungan perusahaan sehingga masih banyak perusahaan yang melaporkan kinerja lingkungan secara berbeda dengan menyesuaikan kompleksitas dan kebijakan masing-masing perusahaan serta menggunakan pedoman pengungkapan lingkungan yang berbeda, walaupun sudah banyak perusahaan yang menggunakan pedoman dari GRI.

Obyek penelitian ini yaitu perusahaan sektor pertanian dan sektor industri dasar \& kimia yang terdaftar di Bursa Efek Indonesia (BEI) tahun 2015-2019. Alasan menggunakan sektor-sektor tersebut dikarenakan dalam penelitian Maulia dan Yanto (2020) membuktikan bahwa sektor pertanian dengan tingkat pengungkapan lingkungan masih sebesar $42,2 \%$ dan sektor industri dasar \& kimia masih sebesar $44,41 \%$. $\mathrm{Hal}$ ini dikarenakan banyak perusahaan yang melaporkan pengungkapan lingkungan berbeda-beda dengan menyesuaikan kebijakan setiap perusahaan.

Perumusan masalah dalam penelitian ini ada dua yaitu, apakah ukuran dewan komisaris, ukuran perusahaan, dan real earnings management mempengaruhi pengungkapan lingkungan? Dan apakah komite audit memperkuat pengaruh ukuran dewan komisaris, ukuran perusahaan, dan real earnings management terhadap pengungkapan lingkungan?

Tujuan penelitian ini yaitu untuk menguji dan membuktikan serta mengetahui pengaruh ukuran dewan komisaris, ukuran perusahaan, dan real earnings management terhadap pengungkapan lingkungan. Selanjutnya untuk menguji dan membuktikan serta mengetahui komite audit memperkuat pengaruh ukuran dewan komisaris, ukuran perusahaan, dan real earnings management terhadap pengungkapan lingkungan.

\section{LANDASAN TEORI}

\section{Teori Keagenan}

Teori keagenan mengidentifikasi hubungan antara pemegang saham dan manajemen yang dilandasi dengan adanya pemisahan kepemilikan dan pengendalian perusahaan, pembuatan keputusan, pemisahan penanggung risiko, dan pengendalian fungsi-fungsi. Manajemen dituntut melakukan kegiatan operasional perusahaan dan mendapatkan wewenang untuk mengambil keputusan terkait kegiatan operasional perusahaan (Dewi, 2019). Teori keagenan memiliki hubungan kesepakatan antara pemegang saham dengan manajer dalam menghasilkan perjanjian kontrak. Pemegang saham ingin mengetahui informasi dan aktivitas manajemen mengenai investasinya dalam perusahaan serta sebagai 
pertanggungjawaban perusahaan mengenai kinerja manajer. Manajer bertanggung jawab secara moral mengoptimalkan keuntungan para pemegang saham dan manajer ingin memperoleh kompensasi sesuai dengan kontrak (Mutmainah \& Indrasari, 2017).

Teori keagenan menyatakan bahwa dengan adanya asimetri informasi, manajer memilih kebijakan memaksimalkan kepentingan pemegang saham baik dalam jangka panjang ataupun jangka pendek. Manajer juga memiliki kepentingan memaksimalkan kesejahteraannya sendiri. Hal ini membuat manajer bertindak seenaknya sendiri tanpa mempedulikan kepentingan pemegang saham (Solikhah \& Winarsih, 2016). Sesuai dengan teori keagenan, pemegang saham menginginkan pelaporan yang akurat dalam menjamin keamanan dananya. Tetapi menurut manajemen hal seperti ini menjadi beban tambahan dan harus berkonsentrasi dalam mengoptimalkan kinerja keuangannya. Manajemen juga harus memastikan tidak terdapat dampak lingkungan dari perusahaan karena tingkat pengungkapan laporan keberlanjutan masih cukup rendah (Maulia \& Yanto, 2020).

\section{Teori Stakeholder}

Teori stakeholder menyatakan bahwa suatu perusahaan dapat memenuhi harapan stakeholder dan menggapi kepedulian stakeholder melalui pengungkapan strategis. Teori stakeholder menjelaskan pemahaman mengenai faktor-faktor motivasi perilaku manajerial dalam pengungkapan sosial dan lingkungan perusahaan. Stakeholder mempunyai hak mendapatkan informasi aktivitas perusahaan dan dapat digunakan dalam pengambilan keputusan. Stakeholder memiliki kebebasan dalam memilih menggunakan informasi tersebut atau tidak (Oktariyani \& Meutia, 2016).

Teori stakeholder yaitu suatu kebijakan yang dibuat oleh perusahaan demi kepentingan individu maupun kelompok. Teori stakeholder mengungkapkan cara pemegang saham dan manajer dalam menciptakan nilai. Hubungan timbal balik antara stakeholder dengan perusahaan yaitu stakeholder menyediakan sumber daya yang dicari oleh perusahaan sedangkan perusahaan berkewajiban memenuhi kebutuhan stakeholder. Teori stakeholder dapat diterapkan dalam pengungkapan lingkungan karena dukungan stakeholder yang kuat dapat meningkatkan pengungkapan sosial yang dilakukan (Oktaviani \& Suryaningrum, 2018).

\section{Teori Legitimasi}

Teori legitimasi menyatakan bahwa setiap perusahaan ada hubungannya dengan masyarakat sehingga mengakibatkan perusahaan harus mematuhi norma-norma yang berlaku dalam sosial masyarakat. Perusahaan yang menjalankan kegiatan operasionalnya sesuai dengan norma-norma yang berlaku maka akan membuat perusahaan semakin legitimate karena perusahaan secara tidak langsung mengabulkan harapan masyarakat terhadap perusahaan dan masyarakat tidak akan menuntut terhadap perusahaan (Suhartini \& Megasyara, 2018).

Teori legitimasi bertujuan untuk membantu perusahaan untuk mengurangi gap kegiatan usaha di masyarakat yang telah merusak lingkungan dengan bertanggung jawab dengan cara memulihkan, menata, dan memperbaiki ekosistem serta kualitas lingkungan agar dapat kembali berfungsi sesuai semula (Pratiwi \& Kurniawan, 2020). Teori legitimasi menyatakan bahwa legitimasi adalah faktor penting dalam perusahaan untuk mengembangkan perusahaan. Kegiatan yang dapat meningkatkan legitimasi yaitu kegiatan yang berdampak pada lingkungan perusahaan seperti perhatian, etika bisnis, dan pengembangan kinerja karyawan. Kepedulian perusahaan terhadap lingkungan melalui pengungkapan lingkungan dapat berdampak positif untuk jangka panjang dan meningkatkan legitimasi (Fashikhah et al., 2018). 


\section{Pengungkapan Lingkungan}

Pengungkapan lingkungan merupakan pengungkapan aktivitas perusahaan yang berdampak terhadap lingkungan. Pengungkapan lingkungan dapat menginformasikan masalah emisi, tingkat sumber daya perusahaan, dan masalah lingkungan lainnya yang berdampak pada konsumen ataupun investor. Pengungkapan lingkungan dapat memberikan kesan yang baik pada masyarakat dan dapat meningkatkan reputasi lingkungan perusahaan (Oktariyani \& Meutia, 2016). Pengungkapan lingkungan merupakan bagian dari corporate social responsibility (CSR) sehingga pengungkapan lingkungan tercermin melalui laporan CSR dalam laporan tahunan. Dalam laporan tahun perusahaan CSR memaparkan tanggung jawab perusahaan dibidang ketenagakerjaan, keselamatan, kesehatan, tanggung jawab kepada konsumen sedangkan pengungkapan lingkungan lebih mengungkapkan tanggung jawab lingkungan dari perusahaan (Sari et al., 2018).

Pengungkapan lingkungan merupakan pelaporan yang menjelaskan dampak kegiatan perusahaan terhadap lingkungan. Kegiatan perusahaan terhadap lingkungan, meliputi daur ulang, pengelolaan limbah, pengelolaan karbon, emisi dan polusi. Meningkatnya kebutuhan terhadap informasi pengungkapan keberlanjutan menjadi pilar utama perusahaan seiring dengan meningkatnya kesadaran pemangku kepentingan dalam pengungkapan lingkungan (Wahyuningrum et al., 2020). Pengungkapan lingkungan sangat berperan dalam program-program pemerintah pengelolaan lingkungan, meliputi PROPER (Program Penilaian Peringkat Kinerja Perusahaan), AMDAL (Analisis Mengenai Dampak Lingkungan), dan sistem manajemen lingkungan (Kurniawan, 2019).

\section{Ukuran Dewan Komisaris}

Undang-Undang No. 40 tahun (2007) pasal 108 tentang Perseroan Terbatas menyatakan bahwa dewan komisaris mempunyai tugas yaitu mengawasi kebijakan jalannya pengurusan dalam menjalankan perseroan dan memberikan nasehat kepada direksi. Selain itu dalam Undang-Undang No. 40 tahun (2007) pasal 114 ayat 2 tentang Perseroan Terbatas menyatakan bahwa dewan komisaris wajib beritikad baik, bertanggung jawab, dan kehati-hatian dalam menjalankan tugas pengawasan perseroan. Dewan komisaris sebagai organ puncak pengelolaan internal dalam perusahaan mempunyai peran terhadap aktivitas pengawasan. Jumlah dewan komisaris semakin besar maka semakin mudah untuk mengendalikan pengawasan yang dilakukan akan semakin efektif. Keberadaan dewan komisaris akan semakin menambah efektivitas pengawasan (Mutmainah \& Indrasari, 2017).

\section{Ukuran Perusahaan}

Besar kecilnya perusahaan diukur melalui besarnya hasil nilai total aktiva atau aset perusahaan, nilai perusahaan, dan nilai equity. Semakin besar ukuran tersebut, maka semakin besar juga ukuran perusahaan (Nurhayati \& Kurniati, 2019). Undang-undang No. 20 Tahun (2008) tentang Usaha Mikro, Kecil, dan Menengah pasal 1 menjelaskan bahwa usaha yang besar adalah kegiatan ekonominya produktif yang dilakukan oleh perusahaan yang memiliki aset bersih lebih besar dari bisnis menengah.

Ukuran perusahaan menggambarkan perusahaan yang besar akan semakin terlihat oleh pembuat kebijakan, regulator, media, dan masyarakat sehingga dapat membuat perusahaan menghadapi peraturan dan tekanan dari pihak eksternal perusahaan (Dewi \& Yasa, 2017). Ukuran perusahaan menggambarkan besar kecilnya suatu perusahaan sehingga diduga dapat mempengaruhi keputusan keuangan perusahaan. Secara umum, ukuran perusahaan diproksikan dengan total aset, rata-rata total penjualan, jumlah penjualan, dan rata-rata total aset. Jumlah total aset sangat besar dibandingkan dengan variabel lainnya, sehingga variabel aset diperhalus menjadi Log (total aset) untuk mengurangi peluang heteroskedastisitas (Kurnia \& Arafat, 2015). 


\section{Real Earnings Management}

Earnings management merupakan kebijakan manajer dalam memaksimalkan utilitas nilai pasar perusahaan. Earnings management dikelompokkan menjadi dua yaitu dari aktivitas real dan accrual. Earnings management melalui aktivitas real mengacu pada permainan angka keuntungan yang dilaksanakan melalui kegiatan yang berasal dari kegiatan operasional (Purwanti \& Utama, 2018). Real earnings management merupakan tindakan yang mempunyai maksud melanggar praktek bisnis dalam proses pelaporan keuangan eksternal dengan maksud mencapai laba yang diharapkan, upaya real earnings management dilakukan bertujuan untuk meningkatkan kinerja jangka pendek tetapi mengorbankan nilai perusahaan jangka panjang yaitu trade-off dalam manipulasi laba aktivitas real (Pratiwi \& Kurniawan, 2020).

\section{Komite Audit}

Komite audit adalah komite yang memiliki fungsi memberikan suatu pandangan terhadap pengungkapan lingkungan. Komite audit memastikan laporan keuangan yang disampaikan oleh perusahaan wajar dan sesuai prinsip akuntansi. Komite audit dapat memberikan pendapat profesional dan independen atas laporan perusahaan (Yusuf et al., 2020). Komite audit mempunyai tugas yaitu membantu dewan komisaris dalam menyajikan laporan keuangan secara wajar sesuai dengan prinsip akuntansi yang berlaku, memastikan struktur pengendalian internal perusahaan berjalan dengan baik, memastikan pelaksanaan audit internal maupun eksternal berjalan sesuai standar audit yang berlaku, dan memastikan tindak lanjut temuan hasil audit dilaksanakan oleh manajemen (Supatminingsih \& Wicaksono, 2016).

Rapat komite audit merupakan koordinasi antara anggota-anggotanya agar dapat menjalankan tugas dengan baik dalam mengawasi laporan keuangan, pengendalian internal, dan mengungkapkan pengungkapan lingkungan (Machmuddah et al., 2017). Atas dasar Keputusan Ketua Bapepam dan LK Nomor Kep-643/BL/2012 dalam peraturan Nomor IX.I.5 tentang Pembentukan dan Pedoman Pelaksanaan Kerja Komite Audit disebutkan bahwa komite audit mengadakan rapat secara berkala paling kurang satu kali dalam tiga bulan (Kementerian Keuangan Republik Indonesia, 2012).

\section{Pengaruh Ukuran Dewan Komisaris terhadap Pengungkapan Lingkungan}

Teori keagenan mengidentifikasi hubungan antara pemegang saham dan manajemen yang dilandasi dengan adanya perbedaan keputusan (Dewi, 2019) untuk menjembatani ditengahi dengan dewan komisaris sebagai pengendali internal yang bertugas memberikan pengawasan yang kuat terhadap kinerja manajemen dalam menjalankan kewajiban seperti melaksanakan pengungkapan lingkungan sebagai bentuk transparansi kepada pemangku kepentingan (Maulia \& Yanto, 2020). Semakin banyak jumlah dewan komisaris dapat semakin meningkat pengungkapan lingkungan oleh manajemen karena dengan adanya pengawasan yang baik dan ketat maka menunjukkan bahwa image perusahaan semakin baik dipandang oleh stakeholder (Suprapti et al., 2019). Hal ini sejalan dengan penelitian yang dilakukan oleh Maulia \& Yanto (2020), Pratiwi \& Kurniawan (2020), dan Mutmainah \& Indrasari (2017) menunjukkan bahwa ukuran dewan komisaris berpengaruh terhadap pengungkapan lingkungan.

$\mathbf{H}_{1}$ : Ukuran dewan komisaris berpengaruh terhadap pengungkapan lingkungan

\section{Pengaruh Ukuran Perusahaan terhadap Pengungkapan Lingkungan}

Teori stakeholder menyatakan stakeholder mempunyai hak mendapatkan informasi aktivitas perusahaan dan dapat digunakan dalam pengambilan keputusan (Oktariyani \& Meutia, 2016) untuk menjembatani ditengahi dengan ukuran perusahaan. Semakin besar ukuran perusahaan maka semakin banyak informasi yang dipublikasikan mengenai pengungkapan lingkungan yang transparansi sehingga 
lebih menarik bagi investor (Maulia \& Yanto, 2020). Perusahaan besar memiliki banyak stakeholder untuk mendukung keberlangsungan perusahaan, sehingga semakin besar ukuran perusahaan informasi pengungkapan lingkungan yang disampaikan kepada stakeholder akan semakin luas dan transparan (Maulia \& Yanto, 2020). Perusahaan yang besar maka semakin dalam tekanan mengungkapkan aktivitas bisnis karena berdampak pada lingkungan sekitar (Nurhayati \& Kurniati, 2019). Hal ini sejalan dengan penelitian yang dilakukan Maulia \& Yanto (2020), Wahyuningrum, et al. (2020), dan Dewi \& Yasa (2017) menunjukkan bahwa ukuran perusahaan berpengaruh terhadap pengungkapan lingkungan.

$\mathbf{H}_{\mathbf{2}}$ : Ukuran perusahaan berpengaruh terhadap pengungkapan lingkungan

\section{Pengaruh Real Earnings Management terhadap Pengungkapan Lingkungan}

Teori keagenan mengidentifikasi hubungan antara pemegang saham dan manajemen yang dilandasi dengan adanya perbedaan keputusan (Dewi, 2019) untuk menjembatani ditengahi dengan real earnings management. Dengan adanya perbedaan informasi dan keputusan, manajemen dapat mempengaruhi angka-angka akuntansi yang disajikan dalam laporan keuangan dengan cara melakukan earning management, sedangkan pemegang saham akan sulit dalam mengawasi tindakan manajemen secara efektif (Ningsih, 2015). Real earnings management merupakan tindakan yang mempunyai maksud melanggar praktek bisnis dalam proses pelaporan keuangan dengan maksud mencapai laba yang diharapkan. Manajemen yang melakukan real earnings management kemudian menggunakan pengungkapan lingkungan perusahaan sebagai upaya untuk mendapatkan dukungan dari para stakeholder dan memberikan image perusahaan yang baik pada masyarakat (Pratiwi \& Kurniawan, 2020).

$\mathbf{H}_{3}$ : Real earnings management berpengaruh terhadap pengungkapan lingkungan

\section{Pengaruh Ukuran Dewan Komisaris terhadap Pengungkapan Lingkungan Dimoderasi oleh Komite Audit}

Teori keagenan mengidentifikasi hubungan antara pemegang saham dan manajemen yang dilandasi dengan adanya perbedaan keputusan (Dewi, 2019) untuk menjembatani ditengahi dengan komite audit sebagai pengawas kinerja dari manajemen perusahaan. Semakin sering komite audit mengadakan rapat akan semakin baik dalam melaksanakan pengawasan terhadap manajemen dan dapat meningkatkan pengungkapan informasi lingkungan (Machmuddah et al., 2017). Dewan komisaris sebagai pengendali internal yang bertugas memberikan pengawasan yang kuat terhadap kinerja manajemen dalam menjalankan kewajiban (Maulia \& Yanto, 2020). Komite audit dapat membantu dewan komisaris dalam mengawasi kinerja manajemen dalam menjalankan kewajiban seperti melaksanakan pengungkapan lingkungan.

$\mathbf{H}_{4}$ : Komite audit memperkuat pengaruh ukuran dewan komisaris terhadap pengungkapan lingkungan

\section{Pengaruh Ukuran Perusahaan terhadap Pengungkapan Lingkungan Dimoderasi oleh Komite Audit}

Teori keagenan mengidentifikasi hubungan antara pemegang saham dan manajemen yang dilandasi dengan adanya perbedaan keputusan (Dewi, 2019) untuk menjembatani ditengahi dengan komite audit sebagai pengawas kinerja dari manajemen perusahaan. Komite audit memastikan laporan keuangan secara wajar sama dengan prinsip akuntansi yang berlaku (Yusuf et al., 2020). Besar kecilnya perusahaan diukur melalui besarnya hasil nilai total aset perusahaan. Semakin besar ukuran tersebut, maka semakin besar juga ukuran perusahaan (Nurhayati \& Kurniati, 2019). Dengan adanya komite audit, maka akan selalu mengawasi nilai total aset perusahaan dan pengungkapan lingkungan dalam menjaga kestabilan dan keberhasilan perusahaan.

$\mathbf{H}_{5}$ : Komite audit memperkuat pengaruh ukuran perusahaan terhadap pengungkapan lingkungan 


\section{Pengaruh Real Earnings Management terhadap Pengungkapan Lingkungan Dimoderasi oleh Komite Audit}

Teori keagenan mengidentifikasi hubungan antara pemegang saham dan manajemen yang dilandasi dengan adanya perbedaan keputusan (Dewi, 2019) untuk menjembatani ditengahi dengan komite audit sebagai pengawas kinerja manajemen perusahaan. Komite audit mengawasi laporan keuangan wajar sama dengan prinsip akuntansi yang berlaku (Yusuf et al., 2020). Real earnings management merupakan tindakan yang mempunyai maksud melanggar praktek bisnis dalam proses pelaporan keuangan dengan maksud mencapai laba yang diharapkan perusahaan (Pratiwi \& Kurniawan, 2020). Dengan adanya komite audit, maka komite audit akan mengawasi tindakan manajemen dalam mencapai laba yang diperoleh perusahaan dan mengawasi pengungkapan lingkungan perusahaan agar mendapatkan legitimasi dan menciptakan image positif dari masyarakat.

$\mathbf{H}_{6}$ : Komite audit memperkuat pengaruh real earnings management terhadap pengungkapan lingkungan

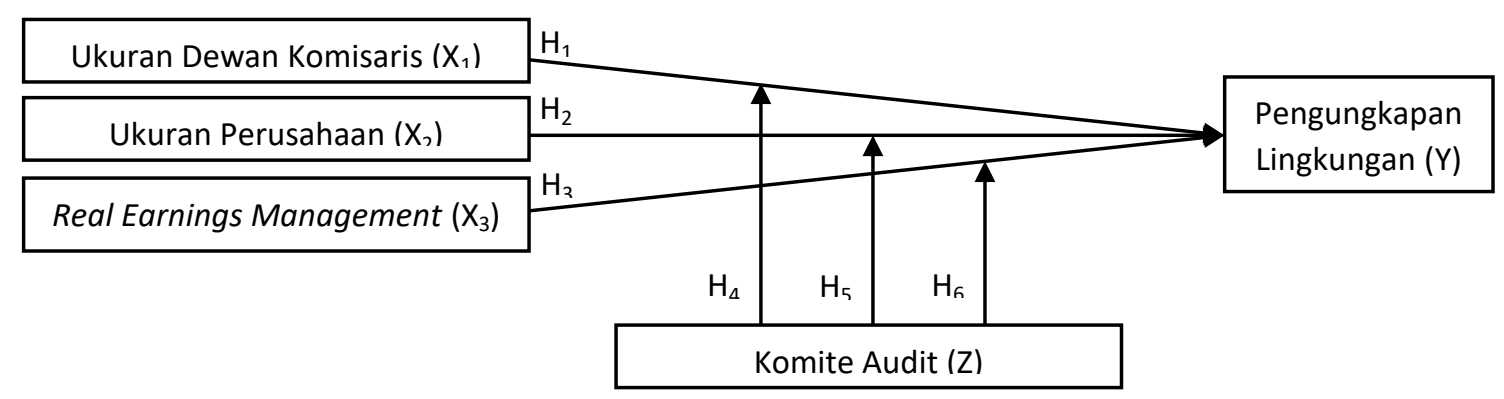

Gambar 1. Kerangka Pemikiran

\section{METODE PENELITIAN}

Penelitian ini menggunakan metode kuantitatif. Jenis data yang digunakan penelitian ini adalah data sekunder. Sumber data penelitian ini adalah laporan tahunan perusahaan sektor pertanian dan sektor industri dasar \& kimia yang terdaftar di Bursa Efek Indonesia (BEI) periode 2015-2019. Teknik penentuan sampel menggunakan teknik purposive sampling diperoleh 12 perusahaan dengan periode 5 tahun menghasilkan sebanyak 60 data. Kriteria yang digunakan dalam Tabel 1.

Tabel 1. Pemilihan Sampel Berdasarkan Kriteria

\begin{tabular}{|c|c|c|c|}
\hline No. & Kriteria & $\begin{array}{l}\text { Luar } \\
\text { Kriteria }\end{array}$ & Total \\
\hline 1. & $\begin{array}{l}\text { Perusahaan sektor pertanian dan sektor industri dasar \& kimia yang } \\
\text { terdaftar di Bursa Efek Indonesia (BEI). }\end{array}$ & - & 104 \\
\hline 2. & $\begin{array}{l}\text { Perusahaan yang tidak melaporkan laporan tahunan maupun laporan } \\
\text { keberlanjutan dan memberikan informasi pengungkapan lingkungan } \\
\text { periode } 2015-2019 \text {. }\end{array}$ & (53) & 51 \\
\hline 3. & $\begin{array}{l}\text { Perusahaan sektor pertanian dan sektor industri dasar \& kimia yang } \\
\text { memiliki profitabilitas negatif (rugi). }\end{array}$ & (33) & 18 \\
\hline \multirow[t]{3}{*}{4.} & $\begin{array}{l}\text { Perusahaan yang tidak mempublikasikan laporan tahunan dalam rupiah } \\
\text { (Rp). }\end{array}$ & (6) & 12 \\
\hline & Total sampel & & 12 \\
\hline & Unit analisis $12 \times 5$ tahun & & 60 \\
\hline
\end{tabular}

Sumber: Hasil Olahan Peneliti, 2021 
Tabel 2. Definisi Operasional dan Pengukuran Variabel

\begin{tabular}{|c|c|c|}
\hline Variabel & Definisi Operasional & Pengukuran \\
\hline $\begin{array}{c}\text { Ukuran } \\
\text { Dewan } \\
\text { Komisaris (X1) }\end{array}$ & $\begin{array}{l}\text { Ukuran dewan komisaris } \\
\text { merupakan banyaknya jumlah } \\
\text { anggota dewan komisaris pada } \\
\text { suatu perusahaan (Djamilah \& } \\
\text { Surenggono, 2017). }\end{array}$ & $\begin{array}{l}\text { DEKOM = Jumlah Anggota Dewan Komisaris } \\
\text { (Djamilah \& Surenggono, 2017) }\end{array}$ \\
\hline $\begin{array}{l}\text { Ukuran } \\
\text { Perusahaan } \\
\quad(\mathrm{X} 2)\end{array}$ & $\begin{array}{l}\text { Besar kecilnya perusahaan diukur } \\
\text { melalui besarnya hasil nilai total } \\
\text { aktiva (Nurhayati \& Kurniati, } \\
\text { 2019). }\end{array}$ & $\begin{array}{l}\text { SIZE = Log (Total Aset) } \\
\text { (Nurhayati \& Kurniati, 2019) }\end{array}$ \\
\hline $\begin{array}{l}\text { Real Earnings } \\
\text { Management } \\
\quad(\mathrm{X} 3)\end{array}$ & $\begin{array}{l}\text { Real earnings management } \\
\text { merupakan tindakan manajemen } \\
\text { yang menyimpang dari praktek } \\
\text { bisnis yang normal yang dilakukan } \\
\text { untuk mencapai laba yang } \\
\text { diharapkan (Ningsih, 2015). }\end{array}$ & $\begin{array}{l}\text { REM }=\text { Arus kas operasi abnormal*(-1) + Biaya } \\
\text { kegiatan produksi abnormal* }(-1)+\text { Biaya } \\
\text { diskresionari abnormal } \\
\text { (Pratiwi \& Kurniawan, 2020) }\end{array}$ \\
\hline $\begin{array}{l}\text { Pengungkapan } \\
\text { Lingkungan }(Y)\end{array}$ & $\begin{array}{l}\text { Pengungkapan lingkungan } \\
\text { merupakan pengungkapan } \\
\text { informasi lingkungan hidup di } \\
\text { dalam laporan tahunan }\end{array}$ & $\begin{array}{l}\text { GRI-G4 total } 34 \text { item pengungkapan lingkungan } \\
\text { menggunakan variabel dummy. } \\
\text { Skor } 1=\text { Mengungkapkan item lingkungan } \\
\text { Skor } 0=\text { Tidak mengungkapkan item lingkungan }\end{array}$ \\
\hline $\begin{array}{l}\text { Komite Audit } \\
\text { (Z) }\end{array}$ & $\begin{array}{l}\text { Komite audit mengadakan } \\
\text { koordinasi dengan anggota } \\
\text { lainnya agar dapat menjalankan } \\
\text { tugas secara } \\
\text { (Machmuddah et al., 2017). }\end{array}$ & $\begin{array}{l}\text { ED = Jumlah item yang diungkapkan } \\
\text { perusahaan / Jumlah item pengungkapan } \\
\text { lingkungan GRI } \\
\text { (Pratiwi \& Kurniawan, 2020) } \\
\text { KOMDIT = Jumlah Rapat Komite Audit } \\
\text { (Machmuddah et al., 2017) }\end{array}$ \\
\hline
\end{tabular}

Sumber: Hasil Olahan Peneliti, 2021

Terdapat tiga variabel independen yaitu ukuran dewan komisaris, ukuran perusahaan, dan real earnings management. Variabel dependen dalam penelitian ini yaitu pengungkapan lingkungan dan variabel moderasi yaitu komite audit. Definisi operasional dan pengukuran variabel dapat dilihat pada Tabel 2.

Teknik analisis data dalam penelitian ini meliputi analisis statistik deskriptif, uji normalitas, uji multikolinearitas, uji autokorelasi, uji heteroskedastisitas, analisis regresi linier berganda, dan pengujian hipotesis. Penelitian ini menggunakan SPSS 25 dalam menganalisis data. Persamaan model pertama dalam penelitian ini sebagai berikut:

$E D=\beta_{0}+\beta_{1}$ DEKOM $+\beta_{2}$ SIZE $+\beta_{3}$ REM $+e$

Persamaan regresi kedua dalam penelitian ini yaitu menggunakan uji interaksi atau Moderated Regression Analysis (MRA) menggunakan perkalian dengan variabel independen. Maka model penelitian keduanya sebagai berikut:

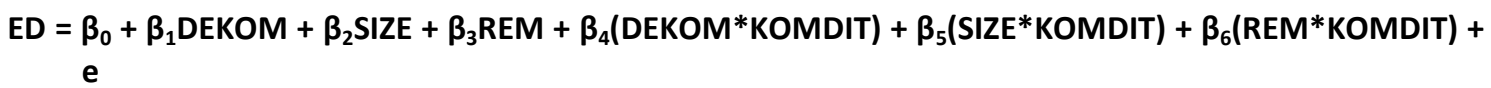

\section{HASIL DAN PEMBAHASAN}


Hasil analisis statistik deskriptif dalam penelitian ini bertujuan untuk mendeskripsikan data penelitian berdasarkan nilai minimum, nilai maximum, mean, dan standar deviation. Tabel 3 . merupakan hasil uji analisis statistik deskriptif pengungkapan lingkungan, ukuran dewan komisaris, ukuran perusahaan, real earnings management, dan komite audit.

Hasil pengujian menunjukkan bahwa rata-rata tingkat pengungkapan lingkungan pada perusahaan sektor pertanian dan sektor industri dasar \& kimia periode 2015-2019 tergolong masih rendah yaitu dibawah $50 \%$. Peringkat tertinggi pada perusahaan sektor pertanian yaitu perusahaan DSNG tahun 2017 sebesar 0,21 atau 21\% dan peringkat tertinggi pada perusahaan sektor industri dasar \& kimia yaitu perusahaan JPFA tahun 2017 sebesar 0,47 atau 47\%. Hal ini dikarenakan pedoman GRI masih bersifat sukarela sehingga masih banyak perusahaan yang melaporkan pengungkapan lingkungan menyesuaikan kebijakan masing-masing perusahaan dan menggunakan pedoman pengungkapan lingkungan yang berbeda, walaupun sudah ada yang menggunakan pedoman GRI.

Tabel 3. Hasil Uji Statistik Deskriptif

\begin{tabular}{crrrr}
\hline & Minimum & Maximum & Mean & \multicolumn{1}{c}{ Std. Deviation } \\
\hline ED & 0,03 & 0,47 & 0,1648 & 0,11043 \\
DEKOM & 3 & 7 & 4,58 & 1,124 \\
SIZE & 6,06 & 7,48 & 6,8777 & 0,45818 \\
REM & 0,10 & 1,67 & 0,5857 & 0,42087 \\
KOMDIT & 4 & 38 & 10,07 & 8,236 \\
\hline
\end{tabular}

Sumber: Hasil Olahan Penelitian melalui SPSS 25, 2021

Sebelum dilakukan pengujian hipotesis dengan regresi linier berganda, maka harus dilakukan uji asumsi klasik untuk menunjukkan kepastian persamaan regresi mempunyai ketepatan dalam estimasi, konsisten, dan tidak bias. Hasil pengujian menunjukkan bahwa data berdistribusi normal, tidak terjadi gejala multikolinearitas, tidak terjadi gejala autokorelasi dan tidak terjadi gejala heteroskedastisitas.

Tabel 4. Hasil Uji Kesesuaian Model (Uji F)

\begin{tabular}{llrrrrl}
\hline Model & & Sum of Squares & df & Mean Square & F & Sig. \\
\hline 1 & Regression & 16,825 & 3 & 5,608 & 14,121 & 0,000 \\
& Residual & 22,242 & 56 & 0,397 & & \\
& Total & 39,067 & 59 & & & \\
\hline
\end{tabular}

Sumber: Hasil Olahan Peneliti melalui SPSS 25, 2021

Tabel 5. Hasil Uji Kesesuaian Model (Uji F) dengan Moderasi

\begin{tabular}{llrrrrl}
\hline Model & & Sum of Squares & df & Mean Square & F & Sig. \\
\hline 1 & Regression & 17,713 & 6 & 2,952 & 7,327 & 0,000 \\
& Residual & 21,354 & 53 & 0,403 & & \\
& Total & 39,067 & 59 & & & \\
\hline
\end{tabular}

Sumber: Hasil Olahan Peneliti melalui SPSS 25, 2021

Tabel 4. hasil uji kesesuaian model (uji F) menunjukkan bahwa nilai signifikan $\mathrm{F}$ sebesar $0,000<0,05$ maka $\mathrm{H}_{0}$ ditolak dan $\mathrm{H}_{1}$ diterima, hal ini artinya semua variabel independen secara signifikan mempengaruhi variable dependen. Tabel 5. hasil uji kesesuain model (uji F) dengan menggunakan variabel moderasi menunjukkan bahwa nilai signifikan $\mathrm{F}$ sebesar $0,000<0,05$ maka $\mathrm{H}_{0}$ ditolak dan $\mathrm{H}_{1}$ diterima, hal ini artinya semua variabel independen dan variabel moderasi secara signifikan mempengaruhi variabel dependen.

Tabel 6. Hasil Uji Koefisien Determinasi $\left(R^{2}\right)$

\begin{tabular}{llccr}
\hline Model & R & R Square & Adjusted R Square & $\begin{array}{c}\text { Std. Error of the } \\
\text { Estimate }\end{array}$ \\
\hline 1 & 0,656 & 0,431 & 0,400 & 0,63022 \\
\hline
\end{tabular}

Sumber: Hasil Olahan Peneliti melalui SPSS 25, 2021 
Tabel 7. Hasil Uji Koefisien Determinasi $\left(\mathbf{R}^{2}\right)$ dengan Moderasi

\begin{tabular}{lcccr}
\hline Model & R & R Square & Adjusted R Square & $\begin{array}{c}\text { Std. Error of the } \\
\text { Estimate }\end{array}$ \\
\hline 1 & 0,673 & 0,453 & 0,392 & 0,63474 \\
\hline
\end{tabular}

Sumber: Hasil Olahan Peneliti melalui SPSS 25, 2021

Tabel 6. hasil uji koefisien determinasi (uji $R^{2}$ ) menunjukkan bahwa besarnya nilai koefisien determinasi $\left(R^{2}\right)$ sebesar 0,400. Hal ini menunjukkan bahwa pengungkapan lingkungan mampu dijelaskan oleh variabel independen sebesar $40 \%$ sedangkan sisanya $60 \%$ dijelaskan oleh faktor lainnya yang tidak dimasukkan dalam model penelitian ini seperti ukuran komite audit, leverage, proporsi dewan komisaris independen, rapat dewan komisaris, dan kinerja keuangan. Tabel 7. hasil uji koefisien determinasi (uji $\mathrm{R}^{2}$ ) dengan menggunakan variabel moderasi menunjukkan bahwa besarnya nilai koefisien determinasi $\left(R^{2}\right)$ sebesar 0,392. Hal ini menunjukkan bahwa pengungkapan lingkungan mampu dijelaskan oleh variabel independen dengan komite audit sebagai variabel moderasi sebesar $39,2 \%$ sedangkan sisanya $60,8 \%$ dijelaskan oleh faktor lainnya yang tidak dimasukkan dalam model penelitian ini seperti dengan menggunakan variabel moderasi proporsi dewan komisaris independen, jumlah rapat dewan komisaris, jumlah anggota komite audit, dan jumlah rapat komite audit.

Berdasarkan Tabel 8. persamaan regresi linier berganda dirumuskan sebagai berikut:

ED = - 1,017 + 2,321 DEKOM - 2,345 SIZE + 0,004 REM

Berdasarkan Tabel 9. persamaan regresi linier berganda dengan moderasi dirumuskan sebagai berikut:

ED = - 1,205 + 2,266 DEKOM - 2,075 SIZE + 0,179 REM + 0,006 MRA1 - 0,003 MRA2 - 0,029 MRA3

Tabel 8. Hasil Uji Parsial (Uji t)

\begin{tabular}{crrrl}
\hline Variabel & Coefficients & t & Sig. & Simpulan \\
\hline (Constant) & $-1,017$ & $-0,411$ & 0,683 & \\
LN_DEKOM & 2,321 & 5,328 & 0,000 & $\mathrm{H}_{1}$ diterima \\
LN_SIZE & $-2,345$ & $-1,658$ & 0,103 & $\mathrm{H}_{2}$ ditolak \\
LN_REM & 0.004 & 0,028 & 0,977 & $\mathrm{H}_{3}$ ditolak \\
\hline
\end{tabular}

Sumber: Hasil Olahan Peneliti melalui SPSS 25, 2021

Tabel 9. Hasil Uji Parsial (Uji t) dengan Moderasi

\begin{tabular}{crrrl}
\hline Variabel & Coefficients & t & Sig. & Simpulan \\
\hline (Constant) & $-1,205$ & $-0,482$ & 0,631 & \\
LN_DEKOM & 2,266 & 3,335 & 0,002 & $\mathrm{H}_{1}$ diterima \\
LN_SIZE & $-2,075$ & $-1,411$ & 0,164 & $\mathrm{H}_{2}$ ditolak \\
LN_REM & 0,179 & 0,823 & 0,414 & $\mathrm{H}_{3}$ ditolak \\
MRA1 & 0,006 & 0,511 & 0,611 & $\mathrm{H}_{4}$ ditolak \\
MRA2 & $-0,003$ & $-0,346$ & 0,731 & $\mathrm{H}_{5}$ ditolak \\
MRA3 & $-0,029$ & $-1,026$ & 0,310 & $\mathrm{H}_{6}$ ditolak \\
\hline
\end{tabular}

Sumber: Hasil Olahan Peneliti melalui SPSS 25, 2021

\section{Pengaruh Ukuran Dewan Komisaris terhadap Pengungkapan Lingkungan}

Hipotesis pertama $\left(\mathrm{H}_{1}\right)$ diterima karena hasil penelitian menyatakan bahwa ukuran dewan komisaris berpengaruh positif terhadap pengungkapan lingkungan. Tabel 8. menunjukkan signifikan $t$ sebesar $0,000<0,05$ dan koefisien 2,321, hal ini menunjukkan bahwa variabel ukuran dewan komisaris memiliki hubungan positif terhadap pengungkapan lingkungan. Hasilnya sejalan dengan teori keagenan, jumlah dewan komisaris yang banyak dapat menjadi pengendalian internal perusahaan yang tinggi yang bertugas memberikan pengawasan yang kuat dan efektif terhadap kinerja manajemen untuk melaksanakan tanggung jawab yang lebih spesifik dalam pengungkapan lingkungan. 
Hasil penelitian ini didukung oleh penelitian Maulia \& Yanto (2020), Pratiwi \& Kurniawan (2020), dan Mutmainah \& Indrasari (2017) yang menunjukkan bahwa ukuran dewan komisaris berpengaruh positif terhadap pengungkapan lingkungan, namun hasil penelitihan ini berbeda dengan yang dilakukan Suprapti, et al. (2019) dan Supatminingsih \& Wicaksono (2016) yang menunjukkan bahwa ukuran dewan komisaris tidak berpengaruh terhadap pengungkapan lingkungan.

\section{Pengaruh Ukuran Perusahaan terhadap Pengungkapan Lingkungan}

Hipotesis kedua $\left(\mathrm{H}_{2}\right)$ ditolak karena hasil penelitian menyatakan bahwa ukuran perusahaan tidak berpengaruh terhadap pengungkapan lingkungan. Tabel 8. menunjukkan signifikan $t$ sebesar $0,103>0,05$, hal ini menunjukkan bahwa variabel ukuran perusahaan tidak memiliki hubungan terhadap pengungkapan lingkungan.

Dari hasil penelitian ini ukuran perusahaan tidak dapat menjembatani teori stakeholder (Oktariyani \& Meutia, 2016) yang menyatakan stakeholder mempunyai hak mendapatkan informasi aktivitas perusahaan dan dapat digunakan dalam pengambilan keputusan, disebabkan semakin besar ukuran perusahaan tidak meningkatkan banyaknya informasi yang dipublikasikan mengenai pengungkapan lingkungan yang transparansi bagi stakeholder. Baik perusahaan kecil maupun besar pasti memiliki masalah yang rumit dalam menerapkan tanggung jawab lingkungan, sehingga perusahaan dalam pengungkapan lingkungan tanpa melihat ukuran perusahaan harus tetap mengungkapkan tanggung jawab lingkungan.

Hasil penelitian ini sejalan dengan penelitian Fashikhah, et al. (2018) dan Oktariyani \& Meutia (2016) yang menunjukkan bahwa ukuran perusahaan tidak berpengaruh terhadap pengungkapan lingkungan, namun hasil penelitihan ini berbeda dengan yang dilakukan Maulia \& Yanto (2020), Wahyuningrum, et al. (2020), dan Dewi \& Yasa (2017) yang menunjukkan bahwa ukuran perusahaan berpengaruh terhadap pengungkapan lingkungan.

\section{Pengaruh Real Earnings Management terhadap Pengungkapan Lingkungan}

Hipotesis ketiga $\left(\mathrm{H}_{3}\right)$ ditolak karena hasil penelitian menyatakan bahwa real earnings management tidak berpengaruh terhadap pengungkapan lingkungan. Tabel 8. menunjukkan signifikan $t$ sebesar $0,977>0,05$, hal ini menunjukkan bahwa variabel real earnings management tidak memiliki hubungan terhadap pengungkapan lingkungan.

Dari hasil penelitian ini real eranings management tidak dapat menjembatani teori keagenan (Dewi, 2019) yang mengidentifikasi hubungan antara pemegang saham dan manajemen yang dilandasi dengan adanya perbedaan keputusan, disebabkan manajemen tidak dapat mempengaruhi angka-angka akuntansi yang disajikan dalam laporan keuangan dan pemegang saham dengan mudah mengawasi tindakan manajemen. Pengungkapan lingkungan bukan untuk menutupi tindakan yang menguntungkan diri sendiri seperti real earnings management yang dilaksanakan oleh perusahaan, melainkan atas bentuk tanggung jawab lingkungan perusahaan akibat dari kegiatan usahanya. Hasil penelitihan ini sejalan dengan yang dilakukan Pratiwi \& Kurniawan (2020) yang menunjukkan bahwa real earnings management tidak berpengaruh terhadap pengungkapan lingkungan.

\section{Pengaruh Ukuran Dewan Komisaris terhadap Pengungkapan Lingkungan Dimoderasi oleh Komite Audit}

Tabel 9. menunjukkan hasil signifikan $\mathrm{t}$ sebesar $0,611>0,05$ maka hipotesis keempat $\left(\mathrm{H}_{4}\right)$ ditolak karena hasil penelitian menyatakan bahwa ukuran dewan komisaris dengan komite audit sebagai variabel moderasi tidak berpengaruh terhadap pengungkapan lingkungan. Rata-rata rapat yang diadakan komite audit masih cenderung kecil disebabkan perusahaan dalam mengadakan rapat menyesuaikan dengan kebutuhan perusahaan yang mendesak dan pembahasan pengungkapan lingkungan juga relatif kecil. Adanya komite audit sebagai variabel moderasi membuat hubungan antara ukuran dewan komisaris dengan pengungkapan lingkungan yang awalnya berpengaruh menjadi tidak berpengaruh. 
Hal ini menunjukkan bahwa ukuran dewan komisaris dengan komite audit sebagai variabel moderasi dalam laporan tahunan belum tentu dijadikan sebagai bahan pertimbangan oleh perusahaan dalam pengungkapan lingkungan, sehingga komite audit tidak dapat menjembatani teori keagenan bahwa masih adanya perbedaan keputusan antara pemegang saham dan manajemen, disebabkan oleh komite audit sebagai pihak manajemen tidak memaksimalkan usahanya dalam meningkatkan pengawasan dalam membantu dewan komisaris dan tidak memaksimalkan dalam pengawasan pengungkapan lingkungan. Komite audit dan dewan komisaris belum memahami secara detail mengenai pengungkapan lingkungan dengan pedoman dari GRI.

\section{Pengaruh Ukuran Perusahaan terhadap Pengungkapan Lingkungan Dimoderasi oleh Komite Audit}

Tabel 9. menunjukkan hasil signifikan $t$ sebesar $0,731>0,05$ maka hipotesis kelima $\left(\mathrm{H}_{5}\right)$ ditolak karena hasil penelitian menyatakan bahwa ukuran perusahaan dengan komite audit sebagai variabel moderasi tidak berpengaruh terhadap pengungkapan lingkungan. Rata-rata rapat yang diadakan komite audit masih cenderung kecil disebabkan perusahaan dalam mengadakan rapat menyesuaikan dengan kebutuhan perusahaan yang mendesak dan pembahasan pengungkapan lingkungan juga relatif kecil. Hubungan antara ukuran perusahaan dengan pengungkapan lingkungan yang awalnya tidak berpengaruh, dengan adanya komite audit sebagai variabel moderasi tetap tidak membuat hubungan antara ukuran perusahaan dengan pengungkapan lingkungan menjadi berpengaruh.

Hal ini menunjukkan bahwa ukuran perusahaan dengan komite audit sebagai variabel moderasi dalam laporan tahunan belum tentu dijadikan sebagai bahan pertimbangan oleh perusahaan dalam pengungkapan lingkungan, sehingga komite audit tidak dapat menjembatani teori keagenan bahwa masih adanya perbedaan keputusan antara pemegang saham dan manajemen, disebabkan oleh komite audit sebagai pihak manajemen tidak memaksimalkan usahanya dalam meningkatkan total aset perusahaan dan tidak memaksimalkan dalam pengawasan pengungkapan lingkungan. Hasil penelitian ini sejalan dengan penelitian Yusuf, et al. (2020) yang menunjukkan bahwa ukuran perusahaan dengan komite audit sebagai variabel moderasi tidak berpengaruh terhadap pengungkapan lingkungan.

\section{Pengaruh Real Earnings Management terhadap Pengungkapan Lingkungan Dimoderasi oleh Komite Audit}

Tabel 9. menunjukkan hasil signifikan t sebesar $0,310>0,05$ maka hipotesis keenam $\left(\mathrm{H}_{6}\right)$ ditolak karena hasil penelitian menyatakan bahwa real earnings management dengan komite audit sebagai variabel moderasi tidak berpengaruh terhadap pengungkapan lingkungan. Rata-rata rapat yang diadakan komite audit masih cenderung kecil disebabkan perusahaan dalam mengadakan rapat menyesuaikan dengan kebutuhan perusahaan yang mendesak dan pembahasan pengungkapan lingkungan juga relatif kecil. Hubungan antara real earnings management dengan pengungkapan lingkungan yang awalnya tidak berpengaruh, dengan adanya komite audit sebagai variabel moderasi tetap tidak membuat hubungan antara ukuran perusahaan dengan pengungkapan lingkungan menjadi berpengaruh.

Hal ini menunjukkan bahwa real earnings management dengan komite audit sebagai variabel moderasi dalam laporan tahunan belum tentu dijadikan sebagai bahan pertimbangan oleh perusahaan dalam pengungkapan lingkungan, sehingga komite audit tidak dapat menjembatani teori keagenan bahwa masih adanya perbedaan keputusan antara pemegang saham dan manajemen, disebabkan oleh komite audit sebagai pihak manajemen tidak memaksimalkan dalam pengawasan manajemen laba dan tidak memaksimalkan dalam pengawasan pengungkapan lingkungan.

\section{SIMPULAN}

Berdasarkan pembahasan pengaruh langsung dapat disimpulkan bahwa ukuran dewan komisaris berpengaruh positif terhadap pengungkapan lingkungan. Ukuran perusahaan dan real earnings 
management tidak berpengaruh terhadap pengungkapan lingkungan. Berdasarkan pembahasan pengaruh moderasi dapat disimpulkan bahwa komite audit tidak dapat memoderasi ukuran dewan komisaris, ukuran perusahaan, dan real earnings management terhadap pengungkapan lingkungan.

Saran bagi perusahaan, diharapkan agar lebih meningkatkan pengungkapan lingkungan perusahaan dengan menggunakan pedoman GRI sebagai bentuk tanggung jawab perusahaan terhadap lingkungan sekitar perusahaan dan lebih transparansi kepada stakeholder dan masyarakat untuk keberlanjutan perusahaan serta dapat menciptakan image yang positif perusahaan dalam jangka panjang.

Saran bagi peneliti selanjutnya, diharapkan dapat melakukan perbaikan-perbaikan tertentu terhadap penelitian ini sehingga hasil penelitian yang diperoleh dapat lebih baik. Peneliti selanjutnya diharapkan dapat menggunakan faktor yang lebih memiliki pengaruh pada pengungkapan lingkungan selain yang digunakan dalam penelitian ini seperti faktor leverage, proporsi dewan komisaris independen, rapat dewan komisaris, kinerja keuangan, dan jumlah anggota komite audit. Serta menggunakan sampel penelitian pada perusahaan yang kegiatan operasionalnya lebih dekat dengan alam, sehingga dapat memperlihatkan tingkat kepedulian perusahaan yang lebih baik terhadap lingkungan.

Berdasarkan hasil penelitian, implikasi dari penelitian ini yaitu pengungkapan lingkungan yang rendah disebabkan oleh perhatian yang kurang baik dari pihak perusahaan. Dengan adanya masalah tersebut maka harus dilakukannya upaya dan usaha dari pihak perusahaan untuk meningkatkan pengungkapan lingkungan dengan cara memperbaiki faktor ukuran dewan komisaris yang dilaksanakan pada perusahaan sektor pertanian dan sektor industri dasar \& kimia. Dengan memperbaiki faktor tersebut diharapkan dapat meningkatkan pengungkapan lingkungan.

\section{REFERENSI}

Dewi, I. A., \& Yasa, G. W. (2017). Pengaruh Ukuran Perusahaan, Profitabilitas, Tipe Industri, dan Kinerja Lingkungan Terhadap Environmental Disclosure. E-Jurnal Akuntansi, 20(3), 2362-2391. https://ojs.unud.ac.id/index.php/Akuntansi/article/view/29935

Dewi, N. A. (2019). Corporate Governance, Profitabilitas, Leverage, dan Pengaruhnya Terhadap Pengungkapan Sosial dan Lingkungan. Journal of Islamic Finance and Accounting, 2(2), 39-62. https://doi.org/10.22515/jifa.v2i2.1950

Dewi, R. K., Tamtomo, A. B., \& Velarosdela, R. N. (2019). Cek Fakta: 11 Perusahaan Tersangka Kebakaran Hutan Kena Sanksi Rp 18,3 Triliun. Kompas.Com. https://nasional.kompas.com/read/2019/02/17/22385631/cek-fakta-11-perusahaan-tersangkakebakaran-hutan-kena-sanksi-rp-183-triliun

Djamilah, S., \& Surenggono. (2017). Corporate Governance, Profitabilitas, Leverage, dan Pengaruhnya Terhadap Pengungkapan Sosial dan Lingkungan. AKRUAL: Jurnal Akuntansi, 9(1), 41-53. https://doi.org/10.26740/jaj.v9n1.p41-53

Fashikhah, I., Rahmawati, E., \& Sofyani, H. (2018). Determinan Environmental Disclosures Perusahaan Manufaktur di Indonesia dan Malaysia. Jurnal Akuntansi Indonesia, 7(1), 31-55. https://doi.org/10.30659/jai.7.1.31-55

Kementerian Keuangan Republik Indonesia. (2012). Keputusan Ketua Bapepam dan LK Nomor KEP643/BL/2012 Peraturan Nomor IX.I.5 tentang Pementukan dan Pedoman Peksanakan Kerja Komite Audit.

Kurnia, L., \& Arafat, M. Y. (2015). Pengaruh Manajemen Laba dan Ukuran Perusahaan Terhadap Biaya Modal Ekuitas Pada Perusahaan Manufaktur yang Terdaftar di Bursa Efek Indonesia. Jurnal IImiah Wahana Akuntansi, 10(1), 45-70. http://journal.unj.ac.id/unj/index.php/wahanaakuntansi/article/view/874 
Kurniawan, I. S. (2019). Pengaruh Corporate Governance, Profitabilitas, dan Leverage Perusahaan Terhadap Environmental Disclosure. Forum Ekonomi, 21(2), 165-171. https://doi.org/10.29264/jfor.v21i2.5930

Machmuddah, Z., Syafruddin, M., Muid, D., \& Utomo, S. D. (2017). Manajemen Laba, Pengungkapan Lingkungan Perusahaan dan Mekanisme Tata Kelola Perusahaan. Jurnal Dinamika Akuntansi Dan Bisnis, 4(1), 57-72. https://doi.org/10.24815/jdab.v4i1.6559

Maulia, D., \& Yanto, H. (2020). The Determinants of Environmental Disclosure in Companies in Indonesia. Jurnal Dinamika Akuntansi, 12(2), 178-188. https://doi.org/10.15294/jda.v12i1.26014

Mutmainah, M., \& Indrasari, A. (2017). Pengaruh Dewan Komisaris dan Leverage Terhadap Environmental Disclosure. Reviu Akuntansi Dan Bisnis Indonesia, 1(1), 47-56. https://doi.org/10.18196/rabin.v1i1.7660.g4758

Ningsih, S. (2015). Earning Management Melalui Aktivitas Riil dan Akrual. Jurnal Akuntansi Dan Pajak, 16(1), 55-66. https://doi.org/10.29040/jap.v16i01.22

Nurhayati, P., \& Kurniati, S. (2019). Determinan Karakteristik Perusahaan Terhadap Environmental Disclosure (Studi Kasus Pada Perusahaan Manufaktur yang Terdaftar di BEI Tahun 2012-2016). Inventory: Jurnal Akuntansi, 3(1), 24-32. https://doi.org/10/25273/inventory.v3i1.4193

Oktariyani, A., \& Meutia, I. (2016). Pengaruh Kinerja Keuangan, Leverage, Ukuran Perusahaan dan Sertifikat Lingkungan Terhadap Kualitas Pengungkapan Lingkungan (Studi Empiris Pada Industri Pertambangan yang Terdaftar di BEI). Jurnal Penelitian Dan Pengembangan Akuntansi, 10(2), 103136. https://doi.org/10.29259/ja.c10i2.8889

Oktaviani, H. D., \& Suryaningrum, D. H. (2018). Pengaruh Profitabilitas, Opini Auditor, dan Ukuran Perusahaan Terhadap Ketepatan Waktu Penyampaian Laporan Keuangan di Bursa Efek Indonesia Periode Tahun 2012-2014. Jurnal Keuangan Dan Bisnis, 16(1), 100-116. https://doi.org/10.32524/jkb.v16i1.368

Pratiwi, L. R., \& Kurniawan. (2020). Pengaruh Real Earnings Management dan Corporate Governance Terhadap Corporate Environmental Disclosure. STATERA: Jurnal Akuntansi Dan Keuangan, 2(1), 65-80. https://doi.org/10.33510/statera.2020.2.1.65-80

Purwanti, A., \& Utama, I. W. (2018). Earning Management Analysis Before and After Implementation of International Financial Reporting Standards (IFRS): Empirical Study of Automotive and Components Companies Registered on the IDX. Journal of Accounting and Strategic Finance, 1(1), 45-56. https://doi.org/10.33005/jasf.v1i01.25

Republik Indonesia. (2007). Undang-Undang No. 40 Tahun 2007 tentang Perseroan Terbatas.

Republik Indonesia. (2008). Undang-Undang No. 20 Tahun 2008 tentang Usaha Mikro, Kecil, dan Menengah.

Sari, G. A., Yuniarta, G. A., \& Wahyuni, M. A. (2018). Pengaruh Mekanisme Good Corporate Governance, Profitabilitas, dan Kinerja Lingkungan Terhadap Environmental Disclosure (Studi Pada Perusahaan Sektor Pertambangan dan Sektor Perkebunan yang Terdaftar di BEI dan Terdaftar di PROPER Tahun 2013-2017). JIMAT (Jurnal Ilmiah Mahasiswa Akuntansi), 9(3), 145-155. https://doi.org/10.23887/jimat.v9i3.20450

Solikhah, B., \& Winarsih, A. M. (2016). Pengaruh Liputan Media, Kepekaan Industri, dan Struktur Tata Kelola Perusahaan Terhadap Kualitas Pengungkapan Lingkungan. Jurnal Akuntansi Dan Keuangan Indonesia, 13(1), 1-22. https://doi.org/10.21002/jaki.2016.01

Suhartini, D., \& Megasyara, I. (2018). Pengaruh Corporate Social Responsibility Disclosure Terhadap Nilai Perusahaan Dengan Profitabilitas Sebagai Variabel Intervening Pada Perusahaan Sektor Pertambangan yang Terdaftar di Bursa Efek Indonesia Tahun 2012-2016. EQUITY: Jurnal Ekonomi, 
Manajemen, Akuntansi, 21(2), 129-140. https://doi.org/10.34209/equ.v21i2.639

Supatminingsih, S., \& Wicaksono, M. (2016). Pengaruh Corporate Governance Terhadap Pengungkapan Lingkungan Perusahaan Bersertifikat ISO-14001 di Indonesia. Jurnal Akuntansi Dan Pajak, 17(1), 32-48. https://doi.org/10.29040/jap.v17i01.54

Suprapti, E., Fajari, F. A., \& Anwar, A. S. (2019). Pengaruh Good Corporate Governance Terhadap Environmental Disclosure. Akuntabilitas: Jurnal Ilmu Akuntansi, 12(2), 215-226. https://doi.org/10.15408/akt.v12i2.13225

Wahyuningrum, I. F., Putri, N., \& Hidayah, R. (2020). Pengaruh Kinerja Keuangan dan Karakteristik Perusahaan Terhadap Pengungkapan Lingkungan di Perusahaan yang Terdaftar di Singapore Exchange. Jurnal Ilmu Lingkungan, 18(2), 417-423. https://doi.org/10.14710/jil.18.2.417-423

Yusuf, M., Karimah, A., Hidayat, A., \& Fajrin, M. (2020). Moderasi Komite Audit Dalam Meningkatkan Pengungkapan Lingkungan Perusahan Sektor Pertambangan dan Transportasi di Indonesia. BRICommerce, Jurnal IImu Manajemen, Bisnis, Dan Keuangan, 1(2), 15-32. https://ejournal.briinstitute.ac.id/index.php/bricommerce/article/view/61 